\title{
The Legal Study on Corporate Social Responsibility in the Realization for Environmental Development In South East Sulawesi
}

\author{
${ }^{1}$ Muhammad Jufri \\ Professor at Law \\ Faculty of Law, Halu Oleo University, Kendari, \\ Indonesia \\ Email: muhjufri.uho@gmail.com \\ ${ }^{2}$ Deity Yuningsih \\ Senior Lecturer \\ Faculty of Law, Halu Oleo University, Kendari, \\ Indonesia
}

\author{
${ }^{3}$ Muh. Sjaiful \\ Senior Lecturer \\ Faculty of Law, Halu Oleo University, Kendari, \\ Indonesia
}

\begin{abstract}
Since 2010, it has been reported that the South East Sulawesi has had some potential mining resource area. Existence of mining companies should accommodate positive impact in environmental sustainability, including community welfare. This is a obligation for the mining company, as well as the corporate social responsibility. It is a mandate of article 74 of Number of 40 of 2007 on the Incorporated Company. In fact, based on our research in legal perspective, the mining company' Corporate Social Responsibility (CSR) of South East Sulawesi has not been implemented as expected by the Act of Number of 40 of 2007 on the Incorporated Company. This is due, among others: (1). Legal arrangements for CSR of Indonesia has not provided legal certainty which can materialize for environmental development. Caused by legal arrangements on CSR of Indonesia in various laws; (2). In reality of implementation for CSR, the mining company of South East Sulawesi, hasnot been well instituted. The CSR obligation of such company, therefore, it is carried out in will of each company. It is not generally oriented in environmental sustainable development.
\end{abstract}

Keywords-The Corporate Social Responsibility and the Environmental Development.

\section{INTRODUCTION}

The existence of Corporate Social Responsibility (CSR) as regulated in Article 74 of Act of Number of 40 of 2007, inspired by a paradigm that company doing business in society, should be responsible for the social problems facing society, so the company must have a concern for the community itself. Article 74 of Act of Number of 40 of 2007 on the Limited Liability Company is not the first formal rule to introduce the concept of Corporate Social Responsibility in Indonesia. About three months, before the Act of Number 40 of 2007 was published, the Government of Indonesia has introduced the concept of Corporate Social Responsibility (CSR), through Article 15 letter b, Act of
Number of 25of 2007 on Capital Investment, which states that every investor is obliged to carry out corporate social responsibility.

Corporate Social Responsibility (CSR) is the Company's commitment to participate in sustainable economic development, to improve the quality of life and the environment that is beneficial to both the Company and the local community. CSR aims to achieve sustainable economic development in order to improve the quality of life and the environment. Our result of research shows that the implementation of each company on CSR, by taking the study of Southeast Sulawesi has not been implemented properly.

\section{METHOD OF RESEARCH}

This research uses normative legal research which is to examine basic norms in Indonesia's positive legal ${ }^{1}$. This research, also uses regulation and conceptual approach ${ }^{2}$. Regulation conceptual is useful for Indonesia regulation which concerned with legal issues of CSR, while the conceptual approach is used to analyze CSR in living law based Indonesia's legal system. Therefore, the conceptual approach is based on legal experts' view. This research uses written legal materials as analysis instrument, containing primer legal materials such as Indonesia Regulations on CSR, and secondary legal materials such as text books, law journal, law article, and scientific paper on law. Authors analyse this topic research using interpretation of legal material substance based on legal theory and legal principle, 
in order to explain the nature of CSR in Indonesia Legal System.

\section{RESULT AND DISCUSSION}

\section{A. The Concept of Corporate Social Responsibility in Indonesia Legal System}

CSR is an ongoing commitment by the business community to act ethically and contribute to the economic development of the local community or the wider community, along with improving the lives of its workers and the whole family. CSR is closely linked to the concept of "sustainable development", with a basic argument that a company in carrying out its activities must base its decisions not solely on the basis of financial factors, but also on environmental and social responsibility both now and in the future. Thus, it can realize sustainable economic development to improve the quality of life and the environment that benefits the company itself and society. CSR objectives, among others:

1. To comply with legal requirements (eg minimum salary and tax payments);

2. To Meet what is expected of the community even though it is not required by law (eg. providing assistance to the surrounding community when it is flooded);

3. To provide what the community needs (eg. school construction assistance and scholarship assistance)

CSR activity in Indonesia today, is still diverse, tailored to the need of the community. Starting from the construction of educational and health facilities, providing capital loans for small businesses, social forestry, scholarships, health counseling, strengthening local wisdom, developing community-based social protection schemes and others. CSR at this level, to create good or improve people's welfare.

CSR for the Company is not just to obtain social consent from the community, to protect the company's business activities or to reduce the environmental loss impacts of the company's activities, but CSR is also an effort to improve the quality of life of the community. Thus, it can increase the company's sensitivity and concern to the social impact of the environment. In addition, CSR is part of corporate social responsibility to overcome the impact of environmental losses as a result of its business activities. Thus, the company not only has economic and legal obligation but also obligation to other interested parties in a wider scope.

The Indonesia government, which is also part of the CSR implementation, is urgently needed to develop partnership with local entrepreneur investing in the region, so that local community can get environmental and socioeconomic attention. This effort is done as the implementation of Act of Number of 40 of 2007 on the Limited Company.

For local government level, CSR needs to be realized into local regulation as the legal basis for CSR implementation in provinces, cities and districts. The Regional Regulation is also expected to arrange for CSR to be properly implemented for each company at the regional level. In addition, local regulation governing CSR, can encourage companies to do CSR well and correctly for local community.

In general, the attention of policymakers in Indonesia today, has shown awareness about the adverse effects of corporate activities. Such bad impacts, must be reduced in such a way, so as not to endanger the welfare of the community, while still conducive to the activities of the company doing business.

The concept and practice of CSR in Indonesia, has shown new development as a necessity. Companies in Indonesia no longer consider CSR as a waste. Indonesian society has considered that CSR should be encouraged, as part of social awareness of humanity and environment. Local government and local community in Indonesia, begin to realize, this effort is also the implementation of Act of Number of 40 of 2007, which for the regional level, elaborated into local regulation.

The existence of CSR in Indonesia, is getting stronger especially after it is stated in the Company Law of Number of 40 of 2007, in Article 74 paragraph 1 mentioned that company which performs business related to natural resources, must perform CSR. The Act of Number of 40 of 2007 does not specify how much the company should spend on CSR, as well as sanctions for violators. Act of Number of 40 of 2007 only stipulates that the CSR is budgeted and calculated as the cost of the company whose execution is carried out with due regard to decency and fairness. Companies that do not perform CSR are subject to sanctions in accordance with laws and regulations. Further provisions concerning this CSR will be governed by the Government Regulation.

Along with the increasingly complex ownership of the company in Indonesia, the CSR concept of the Company is becoming widespread, one of which is the goodwill and commitment of the company to contribute to improving the quality of life of the community, sustainability of community development and local economy, thus contributing to the sustainability of the company. These activities are conducted by building a harmonious relationship between the company and its employees, employees' families, local communities, communities and the environment at large.

\section{B. Implementation of CSR in Southeast Sulawesi Province}

Based on the fact on the implementation of CSR for some companies in Southeast Sulawesi, it seems not yet implemented well because not all companies understand the concept of CSR well. Companies are more inclined to the implementation of the program within the scope of social aspects of the community than the aspect of environmental function preservation.

Some of the constraining factors have not been implemented well, among others: 
1. Disharmony of the Act in implementing the obligation of CSR Program. Implementation of CSR, should use the legal basis contained in the Act of Number of 40 of 2007 on the Limited Company instead of the Act of Number of 4 of 2009 on Mineral and Coal Mining. This is based on the consideration of the principle on Lex specialist derogat legi generali, that the Act of regulates general aspect compared to the legal norm in the Act of Number of 40 of 2007 concerning the provision of CSR, with the consideration that:

a) The Act of Number of 40 of 2007 provides for the special provision contained in Article 74 concerning CSR, while the Act of Number 4 of 2009 on Minerals and Coal Mining, does not set a single article specifically on CSR.

b) The Act of Number of 40 of 2007 in Article 74 (1) states that any company that carries out business activities related to natural resources shall be obligated to implement CSR. Accordingly, under Indonesian law, any mining business in the form of a limited company shall be subject to the Act of Number of 40 of 2007, subject to the provisions of Article 74 paragraph (1) of this act.

c) In the Act of Number 4 of 2009 on Mineral and Coal Mining, does not specify in detail the concept of CSR. This act states that Mining License Holders and Holders of Special Mining Permits shall draw up community development and empowerment program and develop program and plan, in consultation with government, local government and communities. In The Act of Number 40 of 2007 states that the concept of community development and empowerment programs is part of CSR, as stated in Article 1 number 3 in this act. This article states that CSR is the company's commitment to participate in sustainable economic development in order to improve the quality of life and the environment that is beneficial both for the company itself, the local community, and the society at large. This is an obligation as a business entity in the form of a Limited Company. The obligation is not only in community development and empowerment program, but also involved in conducting environmental sustainability program.

d) Article 74 paragraph (4) The Act of Number 40 of 2007 states that further provisions concerning CSR, are regulated through a Government Regulation. The intended Government Regulation is Government Regulation No. 47/2012 on the Limited Company's CSR. The government regulation states that every company as the legal subject has CSR. In addition, in Article 7 of that government regulation, states that Company which does not implement CSR, shall be subject to sanction in accordance with the provision of the law. In the explanation of Government Regulation
No. 47 of 2012 that the meaning of legal sanction in accordance with the provision of the law is any form of sanction stipulated in the relevant legislation. Thus, legal sanction against company which does not implement CSR, will be relegated to the provision of the law governing the object of its business activities, so that for company which performs mining activity, by law, legal sanction will be subject to mining law and business.

2. Local governments in Southeast Sulawesi, no one can guarantee the CSR effectively. This leads to consultation to the government, it could not be done because there is no good communication for local government program that can be synergized with CSR program in each company. The local government in Southeast Sulawesi also has not conducted good supervision on the implementation of every program which must be done by the company, so the form of CSR program implementation is different from the local government program.

3. Indonesia has not set a legal basis on the amount of corporate fund to be spent on CSR, whether budgeted as the cost of the company and as part of the profits obtained by the company. The Act of Number 40 of 2007 and Government Regulation no. 47 of 2012 only specifies the preparation and planning of activity, including CSR budget which should pay attention to decency and fairness. The Notion of "Fairness" of The Act of Number 40 of 2007 and Government Regulation no. 47 of 2012, is a company policy, tailored to the company's financial capability, and potential risks. CSR that must be borne by the company in accordance with its business activity which does not reduce the obligation as stipulated in the provision of the law. In comparison, in the Decree of the Minister of StateOwned Enterprises of the Republic of Indonesia Number KEP-236/MBU 2003 on Partnership of StateOwned Enterprises with Small Enterprises and Community Development Program, it has determined that CSR fund is taken from $1 \%$ net profit after taxes . Likewise in East Kalimantan Regional Regulation No. 3 of 2003 on CSR for Limited Liability Company and Partnership and Community Development Program, has set a budget of $3 \%$ per year for CSR program, and the program, must still be implemented and financed by the company even though the company has not made the profit .

4. Differences Interpretation in CSR implementation by each company, as a result of disharmonization of CSR arrangement, there has been a difference of interpretation of the arrangement of CSR Concept, so nowadays, generally there are companies that think CSR is a voluntary funding program which is not timebound, and the amount of CSR fund is not determined by the law. Companies in Southeast Sulawesi consider CSR only a direct contribution to the community, and 
there are even companies in Southeast Sulawesi which not do $\mathrm{CSR}^{3}$.

5. Unclear position of the department that handles the Implementation, Supervision and Enforcement of Sanctions in the Implementation of CSR, thus affecting the lack of good coordination between the parties involved in the implementation of CSR. In some mining companies in Southeast Sulawesi, there are still companies that do not have a special division that handles CSR programs. Similarly, in terms of supervision and implementation of sanctions against companies in Southeast Sulawesi that do not hold CSR programs, has not been implemented effectively.

6. Lack of community involvement in the preparation and implementation of CSR programs. Implementation of CSR should involve many parties, one of which people will enjoy the results of the CSR program. In this regard, it is appropriate that the community be involved in the preparation and implementation of CSR programs, so as to suit the needs and values that live in the community. The reality is not so, companies in Southeast Sulawesi, do not all carry out the obligations of CSR programming involving the community. if any, in general the implementation of CSR is only the company's own initiatives, the amount of CSR funds, very not meet the value of appropriateness and fairness of the impact of environmental damage. For example, people only accept "ash money", which is a corporate donation of only Rp. 50,000 (five thousand rupiah) ${ }^{4}$.

7. Less strictly the application of sanctions for companies that do not implement CSR. Weak supervision becomes the cause of the effectiveness of the implementation of sanction is not working properly. Moreover, the Act of Number of 40 of 2007 does not strictly set sanction for company that does not perform CSR obligation. This does not provide legal certainty. In various Indonesian regulations governing CSR liabilities, in general, sanction for company is in the form of oral, written and administrative sanction. The most serious sanction is revocation of business license. Whereas there are still more strict sanctions that can be applied to company that does not implement CSR, for example, civil sanction is imposed for company that does not implement CSR, that is unlawful act. Company that does not enforce the law order may be categorized as unlawful, if its business activity has caused harm to the community and resulted in environmental damage.

\section{CLOSING}

The national legal arrangement of CSR lies in several laws and regulations. The diversity of legal regulations becomes a difficulty on legal certainty in implementing CSR. There are laws that explicitly mention the legal obligations for each company to implement CSR, but there are also laws that only use the concept of community development and empowerment programs. The diversity of these laws and regulations can affect legal certainty for the realization of environmentally sustainable development, due to non-compliance or multiple interpretations, which could not guarantee the implementation of CSR in an optimal, fair and useful way, as is the CSR study for companies in Southeast Sulawesi. The authors recommend a model of legal institutional synergy between stakeholders for the realization of sustainable development with environmental insight.

\section{References}

[1] Johnny Ibrahim, 2008, Theory and Methodology of Normative Legal Research, Bayu Media Publishing, Malang.

[2] Peter Mahmud Marzuki, 2007, The Legal Research, Kencana Predana, Media Group, Jakarta, Indonesia.

[3] Muhammad Jufri and Deity Yuningsih, 2016," Perspective Of Progressive Law Towards The Company's Social Responsibility And Environment In Realization Of Green Development In Southeast Sulawesi", International Journal of Advanced Research (IJAR), Volume 11, Issue 4, p. 1128.

[4] Muh. Jufri . Implementation for Mining Activity in Bombana Regency, Southeast Sulawesi Province. The Report of Legal Research, Kendari: 201. p. 33-34. 